Research Paper

International Journal of Biological Sciences

ISSN 1449-2288 www.biolsci.org 2008 4(1):58-62

CIvyspring International Publisher. All rights reserved

\title{
Bioavailability of Heme Iron in Biscuit Filling Using Piglets as an Animal Model for Humans
}

\section{Adrián Guillermo Quintero-Gutiérrez ${ }^{1}$, Guillermina González-Rosendo', Jonathan Sánchez-Muñoz ${ }^{1}$, Javier Polo-Pozo ${ }^{2}$ and José Juan Rodríguez-Jerez ${ }^{3}$}

1. Centro de Desarrollo de Productos Bióticos - CeProBi IPN. Apartado postal No. 24, Yautepec, Morelos, Mexico

2. APC - Europe, S.A. Research Department. Polígono Industrial Congost, Ave. San Julián, 246-258, 08403 Granollers Spain

3. Departamento de Ciencia Animal y de los Alimentos. Facultad de Veterinaria. Universitat Autònoma de Barcelona. 08193. Bellaterra (Barcelona) Spain.

Correspondence to: Adrián Guillermo Quintero Gutiérrez. PO Box No. 24. Post Code 62731, Yautepec, Morelos, Mexico. Tel. +52 (735) 3 9420 20, +52 (55) 57296000 Ext. 82524. Tel and Fax +52 (735) 39418 96. Email: gquinter@ipn.mx

Received: 2007.11.20; Accepted: 2008.02.13; Published: 2008.02.18

The objective of this work was to evaluate the bioavailability of heme iron added to biscuit filling. It comprised two stages: first, the development of the heme iron enriched biscuit filling; second, the evaluation of the bioavailability of the mineral in fattening piglets. Two groups were selected randomly and fed: a) Low iron feed and biscuits with heme iron supplemented filling; b) Normal feed (with ferrous sulphate). Weight and blood parameters were measured every fifteen days. Averages were compared after duplicate analyses. The filling had a creamy appearance, chocolate taste and smell, appropriate spreadability, heme iron content of $2.6 \mathrm{mg}$ per gram and a shelf-life of a month. The heme iron supplemented pigs registered a greater $(\mathrm{P}<0.05)$ weight gain $(27.8 \%$ more than the control group). Mortality in the heme iron group was 10\%, compared to $50 \%$ in the control group. The amount of iron measured in the different compartment was greater in the heme group $(3315 \mathrm{mg})$ than in the control group $(2792 \mathrm{mg})$. However, the amount of iron consumed in the latter was greater. We show that an acceptable product with high heme iron content can be formulated, suitable for use as biscuit filling. The heme iron supplement produced better weight increase and lesser mortality in fattening pigs. The bioavailability of heme iron was $23 \%$ greater $(\mathrm{P}<0.05)$ compared to ferrous sulphate.

Key words: Heme iron, bioavailability, pigs, piglets, iron deficiency.

\section{INTRODUCTION}

Although pervasively widespread in the world, iron is the nutrient with a most pronounced deficiency in humans [1, 2] Many remedial actions have been undertaken; nevertheless, the problem persists for a number of reasons: unspecific diet supplements, poor dietary food combinations and low bioavailability in the iron-bearing products consumed [3-5] Dietary iron occurs in two forms: 1) non-heme iron; derived mainly from vegetable products, and 2) heme iron; only found in products of animal origin $[5,6]$. Heme iron is more easily absorbed in the diet than inorganic iron; because the absorption process is different for each [7].

There are experiences on the use of bovine and pig blood to exploit their high nutritional value and coincidentally eliminate a highly polluting effluent [8].

These experiences show that a base product can be obtained with a high heme iron concentration and good bioavailability for direct consumption or food supplements [5, 9-11]. Satisfactory results have been obtained with the addition of heme derivatives to some foods. For example, in 1993 Walter et al [12], achieved this with biscuits; Pallares et al [13] added bovine blood to a cereal with milk; Aznar and González [14], developed a protein-mineral food supplement (TROFIN), using dried whole blood with hydrolyzed proteins as a base.

Many techniques are available for studying iron bioavailability, which can be classified as: in vitro studies and live studies depending on the model used the latter in either animals or humans [6]. The in vitro studies are cheaper and permit a greater control over the experimental variables. The main limitation of these methods is that they cannot simulate physiological states or some physical and chemical properties and adaptive responses that influence the bioavailability of iron [15]. Although recent methods have been developed attempt to correct these limitations and approach the absorption conditions in the small intestine [16]. Absorption studies in humans continue to be the gold standard in estimating the bioavailability of iron; nevertheless, animals tests are often more practical for the prediction of nutrient bioavailability $[6,17]$. 
The pig is considered a model that shares more human structure and function similarities than other animals. More variables can be measured, such as those related to the diet or growth rate. For these reasons, was chosen as the model for this study [18].

The objective of this work was to evaluate the bioavailability of a heme iron concentrate product incorporated into a chocolate flavor biscuit filling.

\section{MATERIAL AND METHODS}

All analyses were performed by two replicates.

\section{Development of biscuit filling}

A previous study (data not shown) used a factor-by-factor procedure [19], to evaluate several ingredients and formulas (hydrocolloids among them); from this the definitive one was selected, consisting of 9 ingredients (table 1). By means of the researchers' direct observation and using an arbitrary scale (from 0 to 5), the spreadability, flow, colour, smell, flavor, adhesion, gumminess, firmness, cutting effort and radiance characteristics were measured.

Table 1. Formula of Heme iron enrichment filling

\begin{tabular}{|c|c|}
\hline Ingredients & Inclusion $\%$ \\
\hline Glucose & 15.9 \\
\hline Sugar & 39.7 \\
\hline Heme iron & 17.9 \\
\hline Simplesse-100 & 5.0 \\
\hline Skimmed cocoa & 5.0 \\
\hline Cocoa flavor & 4.5 \\
\hline Titanium Dioxide & 1.5 \\
\hline Orange E-110 & 0.5 \\
\hline Water & 10.0 \\
\hline Total & 100 \\
\hline
\end{tabular}

${ }^{1}$ Colorant to $20 \%$.

\section{Microbiological analyses}

Microbiological checks were applied during the process and to the end product, making measurements of total counts, enterobacteria, moulds and yeasts, Salmonella spp. and Escherichia coli.

\section{Working ingredient}

The heme iron used for the fortification is a dark colour dust, obtained from animal blood from healthy pigs that have passed veterinary inspections satisfactorily in registered slaughter houses and hygienically collected after the addition of an appropriate anticoagulant. After the separation of the corpuscular fraction by centrifuging, a pressure pump is used to liberate the hemoglobin contained in the erythrocytes. The hemoglobin is later enzymatically hydrolyzed by a proteolytic enzyme (Alcalase ${ }^{\circledR}$; Novo-Nordisk. Denmark) working within its specific conditions ( $\mathrm{pH} 8,5$ and $50^{\circ} \mathrm{C}$ ). Afterwards, globin peptones were separated from the heme group enriched concentrate by ultrafiltration.
Protein, fat, humidity and ash were analyzed following the methodology proposed in the AOAC [20]; iron and zinc were measured by Flame Atomic Absorption Photospectrometer in a PERKIN-ELMER Photospectrometer, 2100 model [21].

\section{Bioavailability evaluation}

The sample size calculation and the study itself was made with 20 common pigs (Sus scrofa domesticus), Belgian Pietrain; females, 4 weeks old, with an average weight of $7 \mathrm{Kg}$, that only received $100 \mathrm{mg}$ of dextrane iron administration at birth with the intention of producing a slight iron deficiency at weaning.

By means of random selection two groups of 10 piglets each were formed:

1. Study group. This group was fed a low iron diet $(452.7 \mathrm{mg} / \mathrm{Kg})$ and sandwich biscuits with a chocolate flavor filling with added heme iron.

2. Control group. This group was fed normal food, which contained ferrous sulphate $(537.1 \mathrm{mg} / \mathrm{Kg})$.

The iron supplement was given during 20 weeks, making daily inspections, taking their weight and blood samples every fortnight, applying antiparasitic treatment as required and a veterinary check-up monthly.

The blood samples were extracted from the superior cave vein after the pigs were tranquilized with Azaperone (Stresnil®). $7 \mathrm{ml}$ of blood was extracted, of which $3 \mathrm{ml}$ was put in a tube with EDTA to make the red series analyses; the rest of the blood (4 $\mathrm{ml}$ ) was emptied into a tube with separating serum gel to make the biochemical analyses. The samples were transported from the farm to the laboratory refrigerated and they were immediately processed. The hematological measurements were made with an Advia (TM) 120 (Bayer Diagnostics Europe SL, [22], and the biochemical measurements with an COBAS MIRA 89 (ROCHE) Chemical Analyzing System, using the Ferrozine iron A11A00091 ABX commercial kit. The measurement of iron in the liver was made by atomic absorption spectrophotometer with PERKIN-ELMER equipment, model 2100, using a sample taken immediately after slaughtering and deep frozen to $-20^{\circ} \mathrm{C}$ until the analysis 15 days later.

This study was approved by the Autonomous University of Barcelona ethics commission. The end-point criteria for the experiment was either the existence of incapacitating or incurable disease or the completion of study (20 weeks); in both cases, slaughtering was done by administering sodium pentobarbital on the same pig farm [23,24].

\section{Statistical analysis}

The statistical analysis was done with the SPSS 13.0 software. First, descriptive analysis was 
performed, using duplicate determination of initial and final values, and comparing independent averages of the results of both groups.

\section{RESULTS AND DISCUSSION}

Table 2 shows the composition of the filling formulated; it may be observed that heme contribution of iron is $2,6 \mathrm{mg}$ for each gram of filling, so a single biscuit containing 5 grams of product will contribute up to $13 \mathrm{mg}$ of iron, covering $100 \%$ of the recommended iron intake for humans [25]. The 14.1\% protein content, being of hemoglobin and milk serum, is of high biological quality [26]. The product additionally contains small amounts of other nutrients of possible nutritional value. The filling obtained was directly observed to have a creamy appearance, chocolate smell and flavor and appropriate spreadability.

Table 2. Chemical composition of enriched filling with Heme iron (100 g)

\begin{tabular}{|c|c|}
\hline Composition & Quantity \\
\hline Proteins, $g$ & 14.1 \\
\hline Fat, g & 10.9 \\
\hline Carbohydrates, g & 65.2 \\
\hline Ash, g & 5.3 \\
\hline Humidity, $\%$ & 4.5 \\
\hline Iron, mg & 260.0 \\
\hline Zinc, $\mathrm{mg}$ & 0.8 \\
\hline
\end{tabular}

The bioavailability evaluation began with 20 piglets, randomly separated into two groups. The expected values column [27] in table 3 gives some hematological reference parameters for piglets of similar ages and weights and, despite a relatively high variation coefficient, can be used as a guide to verify that the results obtained for most of the parameters studied were within the norm. We observed a high weight variation (variation coefficient 0.23 ), indicating a quite heterogeneous study group.

Given the heterogeneousness of the group, care was exercised to ensure randomness in the separation into groups. Table 3 shows the characteristics of each. Some differences can be noted; nevertheless in all cases these were not statistically significant, therefore we can assume that the groups were not different and that the splitting process was satisfactory.

Of the total number of pigs when the study began, 6 died during the trial, 5 from control group $(50 \%)$ and 1 from heme group $(10 \%)$. There was a risk that the pigs that died shared a common differentiating characteristic compared to the survivors, thereby slanting the results. However, comparing the values of variables of both groups, we observed that although there were slight differences in some variables they had no statistical significance, leading us to consider that there was no factor which influenced mortality differentially in the study groups, since both were subjected to the same treatment and therefore the same stress, probably the cause of the high mortality [28-30].

Table 3. Weight and hematological characteristics of piglets *, according to group and normality

\begin{tabular}{|c|c|c|c|}
\hline \multirow[t]{2}{*}{ Parameter } & \multicolumn{2}{|c|}{$\begin{array}{l}\text { Study groups at the } \\
\text { beginning ** }\end{array}$} & \multirow[t]{2}{*}{$\begin{array}{l}\text { Normal reference } \\
\text { values (26) }\end{array}$} \\
\hline & Heme & Control & \\
\hline Weight, kg & $6.9 \pm 1.7$ & $6.9 \pm 1.7$ & - \\
\hline $\begin{array}{c}\text { Erythrocytes, } \\
10^{6} / \mu 1\end{array}$ & $6.5(1.0)$ & $6.00(0.5)$ & $5-7$ \\
\hline Hemoglobin, g/dl & 11.5 (1.5) & $11.7(1.2)$ & $9-13$ \\
\hline Hematocrite, \% & $34.1(7.4)$ & $32.5(3.6)$ & $36-43$ \\
\hline VCM, fl & $52.6(6.7)$ & $54.3(1.4)$ & $52-62$ \\
\hline $\mathrm{CMH}, \mathrm{pgl}$ & $18.0(3.2)$ & $19.5(1.9)$ & $17-24$ \\
\hline $\mathrm{CCMH}, \mathrm{g} / \mathrm{dl}$ & $34.3(4.9)$ & $36.0(2.1)$ & $29-34$ \\
\hline Seric iron, $\mu / \mathrm{dl}$ & $\begin{array}{c}212.7 \\
(110.7)\end{array}$ & $238.3(84.4)$ & $172 \pm 60$ \\
\hline Leucocytes, $10^{3} / \mu 1$ & $21.5(6.8)$ & $21.5(3.1)$ & $11-22$ \\
\hline Platelets, $10^{3} / \mu \mathrm{l}$ & $\begin{array}{c}448.2 \\
(230.2)\end{array}$ & $\begin{array}{c}408.1 \\
(118.1)\end{array}$ & $200-500$ \\
\hline Lymphocytes, \% & $47.7(12.0)$ & $60.2(6.0)$ & $35-75$ \\
\hline Monocytes, \% & $3.9(2.3)$ & $2.7(1.3)$ & $0-10$ \\
\hline Neutrophils, \% & $42.1(18.6)$ & $35.4(7.2)$ & $20-70$ \\
\hline Eosinophils, \% & $1.9(0.8)$ & $3.1(0.5)$ & $0-10$ \\
\hline
\end{tabular}

Figure 1 shows the behavior of both study groups' weights; there was a slight not statistically significant difference between them from week 8 until week 13 ( $>>0,05)$; from which point the heme supplement group increasingly took off until the end of the study in week 20. Both groups started with an average weight of 6.9 (1.6) $\mathrm{Kg}$; but the increase was much greater in the heme group, their final weight being $56.7 \mathrm{Kg}$, an increase of $49.8 \mathrm{Kg}$. In contrast, the control group, whose final weight average reached $43.9 \mathrm{Kg}$, an increase of $37 \mathrm{Kg}$, giving a statistically significant $(\mathrm{p}<0.05)$ difference of $12.8 \mathrm{Kg}$ between the groups, and agreeing with the results obtained by Perestrelo and Perestrelo [31], who used amino-quelated iron in their supplement and concluded that it reduces mortality and improved growth.

On average, the heme group pigs consumed 10.5 $\mathrm{Kg}$ of sandwich biscuits (498 pieces), a total of 46,737 Kcal, which, when converted to animal weight at the rate of 9,200 Kcal per $\mathrm{Kg}$ [32], gives a total of $5.1 \mathrm{Kg}$ of weight attributable to biscuit consumption. Therefore, the actual difference exclusively due to the heme iron source were $7.7 \mathrm{Kg}(17.2 \%)$ in favor of the heme iron supplement group. 


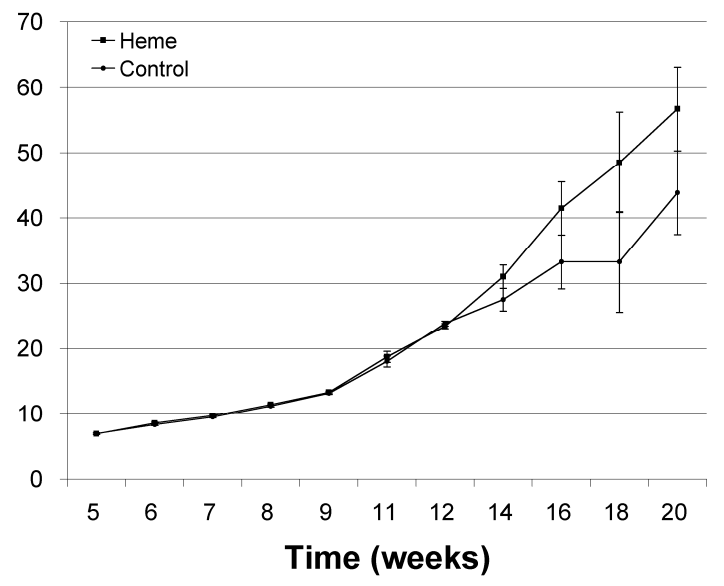

Figure 1. Average of body weight of 20 piglets from 4 to 20 weeks of age.
Table 4 shows the iron measured in tissues and subsequently calculated for each tissue, as well as the sum of each and the percentage relative to the total iron consumed by the pigs throughout the study, according to the supplement group they belonged to. We can observe significant differences between the groups with respect to iron in the blood, but not in the other body parts, although the heme group showed values higher than the ferrous sulphate supplement group as regards both the liver and hemoglobin. The difference in absorption percentage between the groups was significant $(\mathrm{P}<0.05)$; the absorption of heme iron was shown to be $23 \%$ superior to ferrous sulphate.

Table 4. Iron quantity in different compartments (average and standard deviation) and percentage of iron absorption in relation to iron consumed

\begin{tabular}{|c|c|c|c|c|c|c|}
\hline Groups & \multicolumn{3}{|c|}{ Iron quantity mg } & \multicolumn{2}{|c|}{ Absorption percentage * } \\
\hline & $\begin{array}{c}\text { Hemoglobin** } \\
\text { Functional }\end{array}$ & $\begin{array}{c}\text { Liver** } \\
\text { Reserves }\end{array}$ & $\begin{array}{c}\text { Blood* } \\
\text { Circulating }\end{array}$ & Total** & Ingested & \\
\hline Heme iron & $3,032(636)$ & $277(131)$ & $6,2(1.6)$ & $3,315(689)$ & 63,980 & $5.2(1.0)$ \\
Control & $2,498(723)$ & $287(45)$ & $6.7(1.7)$ & $2,792(754)$ & 69,810 & $4.0(1.0)$ \\
\hline
\end{tabular}

* Statistically significant differences $\mathrm{p}<0.05$.

** Statistically not significant differences. $\mathrm{p}>0.05$.

In conclusion, the adverse characteristics of heme iron (dark colour, blood smell and flavor) can be transformed and exploited by its incorporation into a suitable base, which in this case was a chocolate flavored biscuit filling. Mortality was less in the heme iron supplement group of pigs; the weight also was greater in this group and there was a clear difference in favor of the heme iron group in the total measured iron averages; although the heme group pigs consumed less iron; therefore, we can conclude that the measured bioavailability of heme iron was greater than that of ferrous sulphate.

\section{Acknowledgements}

The Faculty of Veterinary medicine of the UAB and APC-Europe thank the COFAA-IPN for the economic support received. In addition, this project was partially grant-assisted by the Spanish Ministry of Science and Technology PROFIT FIT-060000-2000-74 fund.

\section{Conflict of interests}

No conflicts of interests are related to this research paper.

\section{References}

1. McLean E, Egli I, Cogswell M, Benoist B. and Wojdyla, D. Worldwide prevalence of anemia in preschool aged children, pregnant women and non-pregnant women of reproductive age In: Kraemmer K, Zimmermann MB, ed. Nutritional Anemia, Basel Switzerland: Sight and Life Press; 2007: 3-12

2. UNICEF. Micronutrient initiative. Vitamin and mineral deficiency. A global progress report. Ottawa: Micronutrient Initiative; 2004.

3. Looker AC, Dallman PR, Carroll MD, Gunter EW and Johnson CL. Prevalence of iron deficiency in the United States. JAMA, 2002;12:973-6.

4. Wijaya-Erhardt M, Erhardt JG, Untoro J, Karyadi E, Wibowo L. and Gross R. Effect of daily or weekly multiple-micronutrient and iron foodlike tablets on body iron stores of Indonesian infants aged 6-12 mo: a double-blind, randomized, placebo-controlled trial. Am J Clin Nutr. 2007;86:1680-6.

5. Swain JH, Johnson LK, and Hunt JR. Electrolytic iron or ferrous sulphate increase body iron in women with moderate to low iron stores. J. Nutr. 2007; 137:620-7.

6. Fairweather-Tait SJ. Biovailability of nutrients and other bioactive components from dietary supplements: iron. J Nutr. 2001; 131 (Suppl):S1383-S6.

7. Conrad ME and Umbreit JN. Pathways of iron absorption. Blood Cells, Mol Diseases 2002; 29: 336-55.

8. Parés D, Saguer E, Toldra M, and Carretero C. High hydrostatic pressure as a method to reduce microbial contamination of porcine blood. Food Sci Tech Int 2001; 7:117-21.

9. Schumann K, Elsenhans B, Maurer AJ. Iron supplementation. Trace Elem Med Biol. 1998;12:129-40.

10. Fouzia N, Pascal D, Legrand D, Legrand CL and Pascal M. 
Procedimiento biológico de obtención de un preparado alimenticio a base de hierro hémico y preparado alimenticio obtenido con dicho procedimiento. Patente 2263 117. Madrid ES: Oficina Española de Patentes; 2006.

11. Vaghefi N, Nedjaoum F, Guillochon D, Bureau F, Arhan P and Bouglé D. Iron absorption from concentrated haemoglobin hydrolysate by rat. J Nutr Biochem 2005; 16: 347-52.

12. Walter T, Dalman PR, Pizarro F, Velozo L, Peña G. and Bartholmey SJ.. Effectiveness of iron-fortified infant cereal in prevention of iron deficiency anaemia. Pediatrics. 1993;5:976-82.

13. Pallares I. Suplementation of a cereal-milk formula with haem iron palliates the adverse effects of iron deficiency on calcium and magnesium metabolism in rats. Analss Nutr Metab, 1996;2:81-0.

14. Aznar GE, González HR, Achong A. and Díaz BY. Deficiencia de hierro, su control con la aplicación de un biopreparado hierro-proteína (Trofin). Rev Esp Nutr Comunitaria. 1998; 4:242-4

15. Cook JD. Adaptation in iron metabolism. Am J Clin Nutr. 1990;51:301-8.

16. [Internet] Glahn P. A gut issue. Measuring iron bioavailability. 1999. http://www.nps.ars.usda.gov/programs/appvs.htm

17. Wood JR. Methodological issues in assessing bioavailability of nutrients and other bioactive substances in dietary supplements: summary of workshop discussion. J Nutr. 2001;131:S1396-S8.

18. Blachier F, Vaugelade $\mathrm{P}$, Robert V, Kibangou B, Canonne-Hergaux F, Delpal S, Bureau F, Blottière H and Bouglé D. Comparative capacities of the pig colon and duodenum for luminal iron absorption. Can J Physiol Pharmacol. 2007;85:185-92.

19. Toledo O, Jiménez G and Garrido F. Desarrollo y formulación de alimentos: VI taller de herramientas de cálculo en ingeniería de alimentos. Valencia, ES: Universidad Politécnica de Valencia; 1995.

20. Association of Official and Analitical Chemist. Official Methods of Analysis of AOAC international, 16th ed, 5th revision, Vol I and II. Maryland USA: Association of Official and Analitical Chemist. 1999.

21. Penner, M.H. Spectroscopy. In: Nielsen SS. Ed. Food Analysis 3rd ed. New York. Springer. 2003.

22. Knoll JS. Clinical automated hematology systems. In: Schalm's editor. Veterinary Hematology. Baltimore USA: Lippincott Williams \& Wilkins; 2000:3-11

23. Close B, Banister K, Baumans V, Bernoth EM, Bromage N. and Baunvan J. Recommendations for euthanasia of experimental animals: Part 1. Lab Anim, 1996;4:293-316.

24. Close B, Banister K, Baumans V, Bernoth EM, Bromage N. and Baunvan J. Recommendations for euthanasia of experimental animals: Part 2. Lab Anim,1997;1:1-32.

25. Institute of medicine (US), Dietary reference intakes. Vitamin A, vitamin $\mathrm{K}$, arsenic, boron, chromium, copper, iodine, iron, manganese, molybdenum, nickel, silicon, vanadium and zinc, Washington, D.C. USA: National Academy Press; 2001.

26. Nelson DL and Cox MM. Amino acids peptides and proteins. In: Lehninger's principles of Biochemistry, 4th ed. New York: W.H. Freeman and Company; 2005.

27. Aiello SE. and Mays A. Guía de referencias en el manual Merk de veterinaria. $5^{a}$ ed. Barcelona, ES: Doyma; 2000:2452-6.

28. Bonelli AM and Schifferli CS. Porcine Stress Syndrome. Arch Med Vet. 2001;33: 125-35.

29. Riojas-Valdés VM, Canales-Zambrano JC, Gómez-de la Fuente JC, Dávalos-Aranda G, Hernández-Vidal G and Salinas-Meléndez JA. Frecuencia alélica del síndrome de estrés porcino en Nuevo León, mediante análisis PCR-RFLP 2005. Vet Méx. 2005;36: 262-67

30. Madonna B. Pig Trucking \& Handling-Stress and fatigued pig. Advanced in pork production 2005;16:1-7.
31. Perestrelo VR and Perestrelo VH. La administración de diaminoacidoquelato de hierro en cerdas gestantes mejora el peso de los lechones y la homogeneidad de las camadas al nacimiento. Anaporc 1998;183:85-8.

32. Goodwing DH. Raciones equilibradas en: Producción y manejo del cerdo. Zaragoza, ES: Acribia. 1975:67-76. 